\title{
Epidemiological investigation, characterization and antifungal susceptibility profile of Microsporum canis isolated from pet animals
}

\author{
Abhishek D. Singh ${ }^{1 *}$, Chanchal Debnath ${ }^{1}$, and Abhiroop Banerjee ${ }^{2}$ \\ ${ }^{1}$ Department of Veterinary Public Health, Faculty of Veterinary and Animal Sciences, West Bengal University of \\ Animal and Fishery Sciences (WBUAFS), 37, K.B. Sarani, Belgachia, Kolkata, West Bengal, India \\ ${ }^{2}$ Department of Veterinary Microbiology, Faculty of Veterinary and Animal Sciences, West Bengal University of \\ Animal and Fishery Sciences (WBUAFS), 37, K.B. Sarani, Belgachia, Kolkata, West Bengal, India
}

SINGH, A. D., C. DEBNATH, A. BANERJEE: Epidemiological investigation, characterization and antifungal susceptibility profile of Microsporum canis isolated from pet animals. Vet. arhiv 91, 339-347, 2021.

\section{ABSTRACT}

Dermatophytoses is a very old and neglected ailment in man as well as animals. The development of antifungal resistance is another emerging issue. Among the different etiologies, Microsporum canis plays a crucial role. The present study was undertaken to investigate the epidemiology of, characterize, and explore the antifungal susceptibility profile of $M$. canis isolated from pet animals. A total of 97 (59.15\%) (Dog-46, Cat-51) isolates were identified as $M$. canis by using PCR. The prevalence of $M$. canis was highest in puppies (19.1\%) and kittens $(25.78 \%)$ in relation to age. No sexual predisposition was found in this study. Seasonal distribution revealed the highest prevalence in summer and lowest in winter. Resistance against Fluconazole and Griseofulvin was observed in a few isolates. The results indicate the need to properly identify the pathogen, and to be cautious in selecting the drug for treatment in order to stop the further development of resistant dermatophytes.

Key words: dermatophyte; dogs; cats; PCR; drug resistance

\section{Introduction}

Tinea, Ringworm, or Dermatophytoses is a common mycoses of the skin caused by dermatophytes. Microsporum canis, one of the zoophilic zoonotic dermatophytes is frequently isolated from both dogs and cats, with or without skin lesions (CAFARCHIA et al., 2006; COPETTI et al., 2006). It is the most common cause of tinea capitis, tinea corporis, and ringworm in most areas worldwide (CANO et al., 2005, MARAKI et al., 2007). It has also been known to survive in the environment for years by forming dormant spores

(MIGNON and LOSSON, 1997). Pet animals infected with $M$. canis should be considered as a potential risk, and should not be mixed with other animals, as minimal exposure can lead to infection (MANCIANTI et al., 2003; DA-CUNHA et al., 2019).

Direct microscopic examination, followed by in vitro isolation and identification have been used as the 'gold standard' diagnostic technique for different species of dermatophytes (PANASITI et al., 2006). While microscopic examination is

\footnotetext{
*Corresponding author:

Dr. Abhishek Dharm Singh (MVSc, Ph.D. Scholar) Department of Veterinary Public Health, Faculty of Veterinary and Animal Sciences, West Bengal University of Animal and Fishery Sciences (WBUAFS) 37, K.B. Sarani, Belgachia, Kolkata-700 037, West Bengal, India, Phone: +91 77 0006 1276, E-mail: abhimaoa@gmail.com,
} 
rapid and inexpensive, it can be non-specific and requires skilled personnel to identify the fungal characteristics, which leads to a higher number of false-negatives, up to as many as 15\% (MITCHELL et al., 1994). Thus, for improved and better identification, a more rapid and precise diagnostic test is required (GARG et al., 2009). Since PCR technology is rapid and can distinguish between species and strains by producing specific bands on agarose gel electrophoresis, in this study a pair of published primers (MC1F and MC1R) were used for further confirmation of the isolated M. canis (LIU et al., 2001).

The treatment of cutaneous fungal infections depends predominantly on the site and spread of infection, and the antifungal agent used. Usually, topical application of different antifungal agents is generally used, but chronic infections, such as tinea corporis, often require the administration of drugs through a systemic route (RENGASAMY et al., 2017). Several antifungals, such as Ketoconazole, Fluconazole, Griseofulvin, and Itraconazole, have been reported to have significant activity against dermatophytosis (RENGASAMY et al., 2017; RAJAGOPALAN et al., 2018). The current emergence of antifungal resistance of clinical isolates has led to failure in the treatment of mycoses (ALCAZAR-FUOLI and MELLADO, 2014). Therefore, testing the antifungal's susceptibility will assist in selecting an effective antifungal agent against the clinical isolates (ALCAZARFUOLI and MELLADO, 2014). The motive of this research was therefore also to determine the in vitro antifungal sensitivity of PCR-confirmed $M$. canis clinical isolates against six frequently used antifungal drugs, viz. Fluconazole, Itraconazole, Ketoconazole, Griseofulvin, Miconazole, and Amphotericin-B.

\section{Materials and methods}

Collection of study samples. From October 2016 to September 2018, a total of 630 samples from dogs $(n=406)$ and cats $(n=224)$ were collected from veterinary clinics (both private and public) who showed signs of dermatophytoses, such as alopecia, annular plaques, scaling, crusts and desquamation of the paws, in and around Kolkata, West Bengal, India. Both dogs and cats were grouped according to breed, age, sex, and place of living, as rural or urban. Nine different breeds of dog, namely Indian pariah dog $(n=84)$, Labrador Retriever (63), Pug (58), Dachshund (55), German Spitz (42), Beagle (36), German Shepherd (27), Golden Retriever (22) and Rottweiler (19) were recorded in the present study. For cats, non-descript Indian (179), Persian (34), and Himalayan (11) breeds were recorded. Animals below 6 months of age were considered as young while those above 6 months of age were regarded as adults. Animals with no history of antifungal therapy in the last 6 months were selected to study the actual MIC of the drug, and to avoid resistance which could have developed in the course of treatment. Also, grouping was done in respect to the season of collection: Autumn (October and November), Winter (December to March), Summer (April to June) and Monsoon/Rainy (July to September). This study of dermatophytoses in pet animals was carried out at the Department of Veterinary Public Health (VPH), Faculty of Veterinary and Animal Sciences, West Bengal University of Animal and Fishery Sciences (WBUAFS), Kolkata, West Bengal, India. Skin samples were collected by scraping, starting from the rim through the center of the suspected lesions, using a sterile scalpel blade, after cleaning the affected sites with $70 \%$ (v/v) isopropyl alcohol. The samples were then wrapped in clean sterile black paper and packed in a sterile polyethylene pouch. Epidemiological data in relation to the animal concerned were also noted. Samples were then transported without cooling to the laboratory for further processing, after proper labeling. No transport medium was added and moisture of any kind was avoided.

Identification by routine methods. The specimens were inoculated into both Sabouraud's Dextrose Agar (SDA) medium (containing 0.5\% cycloheximide and $0.05 \%$ chloramphenicol) and Dermatophyte Test Medium (DTM). Both media were procured from $\mathrm{BD}^{\circledR}$. SDA plates were then incubated at $28{ }^{\circ} \mathrm{C}$ for around 4 weeks, and observed regularly for any kind of fungal growth. If no growth was established after four weeks, it was taken as negative for the growth of fungi. DTM plates were also incubated at $28{ }^{\circ} \mathrm{C}$ for up to 3 weeks, and were observed for color changes 
(ROBERT and PIHET, 2008). Microscopical examination of the cultures was done by removing a fragment of aerial mycelium with an inoculation loop, and staining with a drop of lactophenol cotton blue. Identification and differentiation of the fungal isolates were done according to the "Dermatophyte identification scheme" described by KONEMAN and ROBERTS, 1985. Macroscopically, the isolates were examined for different colony morphology, pigmentation, and microscopically evaluated by lactophenol cotton blue staining and slide culture techniques. Other tests, such as the rice grain test and in vitro hair perforation test were also performed to establish the presence of $M$. canis (ROBERT and PIHET, 2008).

Identification of $M$. canis by PCR. A HiPurA ${ }^{\mathrm{TM}}$ Fungal DNA purification Kit (MolBio ${ }^{\mathrm{TM}}$ Himedia $^{\circledR}$, India) was used for the isolation of DNA from dermatophyte isolates, according to the protocol given by the manufacturer. In brief, fungal mycelium was collected in a cryovial (Sigma-Aldrich ${ }^{\circledR}$ ), mixed with lysis buffer, and grounded in liquid nitrogen. A HiShredder (MolBio ${ }^{\mathrm{TM}}$ Himedia $\left.^{\circledR}\right)$ was used to remove the precipitated protein and other contaminants. The fraction obtained was mixed with a buffer solution for the proper binding of DNA to the spin column. The final solution was passed through a silica column, followed by washing steps to remove trace contaminants. Lastly, the elution buffer was used to obtain high-quality DNA. PCR was performed with $25 \mu \mathrm{L}$ reaction buffer, which consisted of $1 \mu \mathrm{L}(100 \mathrm{pg})$ of genomic DNA, 50 millimolar $(\mathrm{mM}) \mathrm{KCl}, 10 \mathrm{mM}$ Tris-HCL $(\mathrm{pH}-$ 9.0), $10 \mathrm{mM}$ Sodium chloride $(\mathrm{NaCl}), 0.5 \mathrm{~m} \mathrm{M}$ DTT, $2.5 \mathrm{mM}$ Magnesium chloride $\left(\mathrm{MgCl}_{2}\right)$, Triton X-100 (0.1\%), 200 micromolar $(\mu \mathrm{M})$ of each dNTP (dATP, dCTP, dGTP and dTTP), 0.5 units (U) of Taq DNA polymerase and 50 picomole (pmol) each of MC1F (5'-CGGGGGAAGTTTACAATCCT-3') and MC1R (5'-GGTTGGCGGAATGATCGATA$3^{\prime}$ ) specific primers (Sigma-Aldrich ${ }^{\circledR}$ ) made up to volume with pure sterile nuclease-free water (Molecular grade). The PCR was performed by using Thermal Cycler $\left(\mathrm{Genei}^{\circledR}\right)$ with the following protocol: initial denaturation at $95{ }^{\circ} \mathrm{C}$ for $60 \mathrm{~s}$, and 35 cycles at $95{ }^{\circ} \mathrm{C}$ for $15 \mathrm{~s}, 55^{\circ} \mathrm{C}$ for $30 \mathrm{~s}$ and 72 ${ }^{\circ} \mathrm{C}$ for $60 \mathrm{~s}$ and final elongation at $72{ }^{\circ} \mathrm{C}$ for 10 min. A tube containing the DNA isolated from the procured culture of M. canis from Microbial Type Culture Collection and Gene Bank (MTCC), India with code number 2820, was used as a positive control. The resulting PCR amplified products were separated in agarose gel $(1 \%)$ in $0.5 \mathrm{X}$ Tris-borateEDTA buffer, stained with Ethidium bromide, and then images were obtained using the Gel Doc imaging system by Bio-Rad ${ }^{\circledR}$ (LIU et al., 2001).

Antifungal susceptibility test (AST). AST was performed using the Broth Micro-dilution Assay method recommended by Clinical Laboratory Standard Institute (CLSI), approved standard M38-A (NCCLS, 2002), against six commonly used antifungal drugs, namely: Fluconazole, Itraconazole, Griseofulvin, Ketoconazole, Miconazole and Amphotericin-B (all procured from Sigma-Aldrich ${ }^{\circledR}$ ). All the agents were dissolved using 100\% dimethyl sulfoxide, except Fluconazole (in sterile water) to the strength of $1 \mathrm{mg} /$ $\mathrm{ml}$, which were diluted in Roswell Park Memorial Institute (RPMI) 1640 Medium with l-glutamine but without sodium bicarbonate, and buffered at pH 7.0 with morpholinepropanesulfonic acid. Final concentrations ranged from 32.0 to $0.06 \mu \mathrm{g} / \mathrm{mL}$ for all the drugs, except Fluconazole which was 64 to $0.13 \mu \mathrm{g} / \mathrm{mL}$.

A total of $97 \mathrm{M}$. canis cultures were cultivated on potato dextrose agar separately for 7-10 days at $25 \pm 3{ }^{\circ} \mathrm{C}$. Sterile normal saline solution (85\%) was added to the slants and the cultures were gently scrubbed with a sterile loop to dislodge the conidia from the hyphal mat. The individual suspension was then transferred to a sterile tube, vortexed, and left for half an hour at room temperature to sediment the heavy particles. The optical density of the supernatant containing conidia and fine particles of hyphal fragments was read by double beamed UV spectrophotometer at $530 \mathrm{~nm}$, adjusted to the transmittance of $60-70 \%\left(\sim 2\right.$ to $4 \times 10^{6}$ cells $\left./ \mathrm{mL}\right)$ and diluted with RPMI 1640 medium, to acquire the final inoculum concentration of approximately 0.4 to $5 \times 10^{4}$ cells $/ \mathrm{mL}$. Sterile microdilution plates (Tarsons ${ }^{\circledR}$ ) were taken, and Column 1 was filled with $200 \mu \mathrm{L}$ of inoculums to serve as a positive growth control. Columns 2 to 12 were filled with both inoculum and serially diluted antifungal agent $(100 \mu \mathrm{L}$ each). As a negative control, a column 
filled with $200 \mu \mathrm{L}$ of RPMI-1640 (growth medium) was kept along with the sterile microdilution plate. The microdilution plates were then incubated at 28 ${ }^{\circ} \mathrm{C}$, and were interpreted visually after 7 days of incubation. MIC 90 values were determined after conducting a visual comparison with growth in the positive control tube at a $24 \mathrm{hrs}$ interval. The MIC value for the Azole derivatives and Griseofulvin was interpreted as the point at which the organism was inhibited $80 \%$ compared with the growth in the control well, and for Amphotericin-B it was the point of $100 \%$ growth reduction.

\section{Results}

Three different species of 164 dermatophytes were isolated from a total of 630 animal cases, giving an overall prevalence of dermatophytoses of $26.03 \%$ in the study population. Among the 164 isolates, M. canis was identified from 107 cases $(65.24 \%), T$. mentagrophytes from 48 cases (29.27\%), and M. gypseum from 9 cases (5.49\%) using various conventional methods. All the isolates showed the development of pink color in the DTM medium within the stipulated time period of seven to ten days of inoculation (ROBERT and PIHET, 2008). Molecular identification using PCR revealed 97 (59.15\%) isolates as $M$. canis, indicating a deviation of $6.1 \%$ in conventional methods over the molecular method of identification.

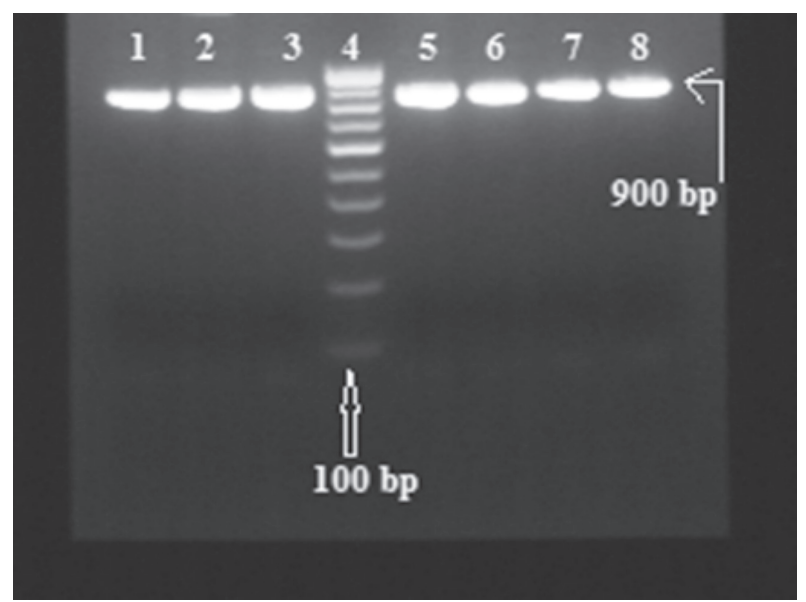

Fig. 1. Identification of $M$. canis isolates by PCR

(1 to 3-Cat isolates, 4- 100 bp ladder, 5- Positive control (MTCC-2880), 6 to 8- Dog isolates).

As shown in Fig. 1, a band of 900 base pairs (bp) was generated in all the isolates which were specific for $M$. canis. The corresponding isolates also produced the characteristic cottony to wooly aerial mycelium that became powdery and light brown in the center on the obverse side (Fig. 2a), while the reverse side showed brilliant brown surrounded by the yellow pigment (Fig. 2b). M. canis isolates also produced a bright yellow pigment on the rice grain test when incubated at $28{ }^{\circ} \mathrm{C}$ for 7 days. The in vitro hair perforation test was negative for $M$. canis isolates. Under Lactophenol cotton blue (LCB) staining, M. canis isolates revealed numerous large, multi-septate and spindle-shaped, rough, thickwalled macroconidia. Microconidia were few, and if present were single celled (Fig. 3).

A further epidemiological study was conducted only in respect of the 97 PCR confirmed M. canis isolates. In the present study, out of the total 97 isolates of $M$. canis, 46 were obtained from dogs and 51 from cats, indicating that the occurrence was higher in cats than in dogs. Dachshund (13/55, $23.63 \%$ ) was the most common breed infected with $M$. canis followed by Beagle (7/36, 19.44\%), Golden Retriever (4/22, 18.18\%), Labrador Retriever (11/63, 17.46\%), Pug (7/58, 12.07\%), German Shepherd (2/27, 7.41\%) and Indian Pariah $(2 / 84,2.38 \%)$. No $M$. canis isolates were obtained from German Spitz and Rottweiler. In cats, M. canis was most frequently isolated from Persian (15/34, $44.12 \%)$, followed by Non-descript Indian (34/179, $18.99 \%)$ and Himalayan breeds $(2 / 11,18.18 \%)$. From Table 1, it is clear that there is a higher prevalence rate in puppies and kittens as compared to dogs and cats. There was no association in the isolation rates of the fungus in comparison to the gender of the animals. Since the dermatophytes are reported to be a disease closely related to different climatic conditions, the monthly distribution of isolates was compared with different climatic parameters, such as the average monthly rainfall, average monthly temperature, and average monthly humidity data of the study area. It was observed that the isolation of $M$. canis was comparatively highest in the summer season for both dogs and cats, followed by autumn, the rainy season, and winter. Dogs from rural areas had a higher isolation rate than those from urban areas, while in cats there was no difference (Table 1). 


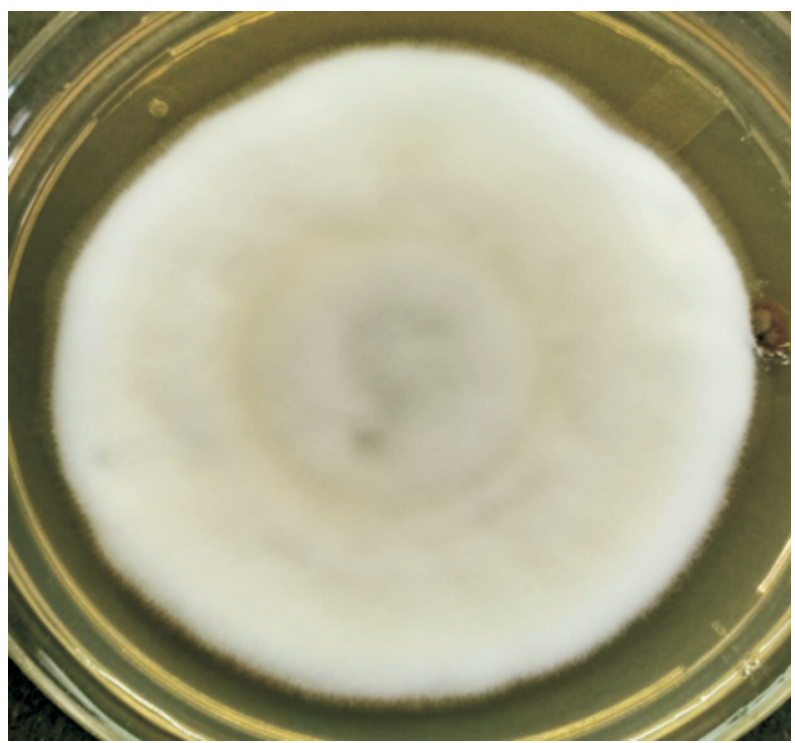

Fig. 2a. Growth of M. canis on Sabouraud's Dextrose Agar (obverse side)

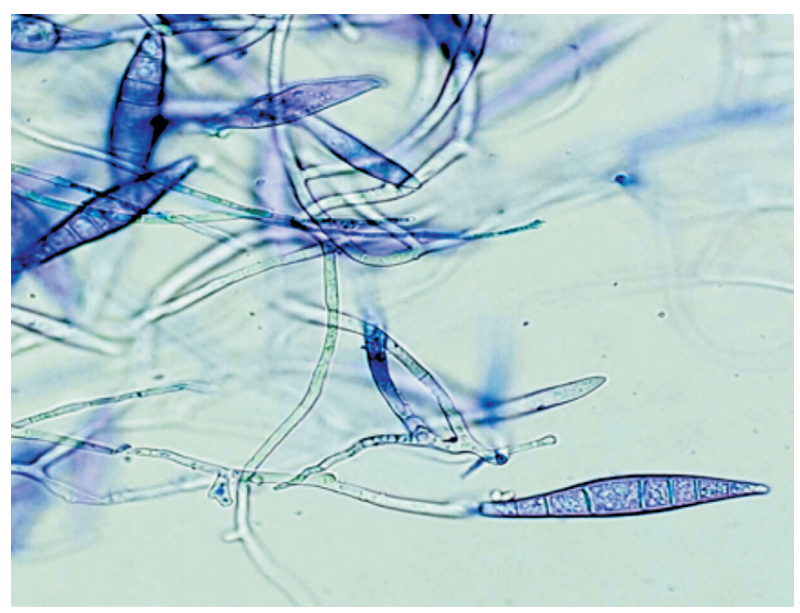

Fig. 3. Lactophenol cotton blue mount under a Phase contrast microscope (100X) showing macroconidia

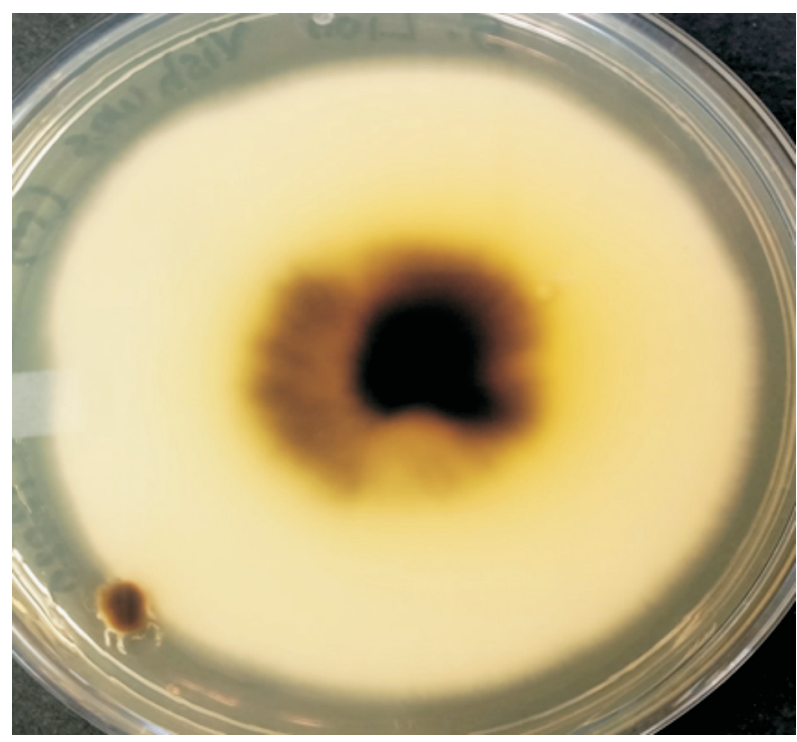

Fig. 2b. Growth of M. canis on Sabouraud's Dextrose Agar (reverse side)

The antifungal susceptibility pattern of $97 \mathrm{M}$. canis isolates revealed that most of the isolates showed almost similar patterns of susceptibility against the particular antifungal agent tested. MIC 50 values were as low as $0.06 \mu \mathrm{g} / \mathrm{mL}$ for Ketoconazole, Miconazole, and Amphotericin-B and highest for Fluconazole $(16 \mu \mathrm{g} / \mathrm{mL})$. MIC 90 values for Fluconazole and Griseofulvin were 32 $\mu \mathrm{g} / \mathrm{mL}$ and $1 \mu \mathrm{g} / \mathrm{mL}$ respectively (Table 2 ).

Table 1. Epidemiological study of the prevalence of $M$. canis in dogs and cats, considering different variables

\begin{tabular}{|l|l|l|c|c|c|}
\hline \multirow{2}{*}{ Sl. No } & $\begin{array}{l}\text { Criteria/ } \\
\text { variables }\end{array}$ & \multicolumn{1}{|c|}{ Data } & Total number & M. canis isolated & Prevalence (\%) \\
\hline \multirow{4}{*}{1.} & \multirow{3}{*}{ Age } & Dogs- Adult & 317 & 29 & 9.15 \\
\cline { 3 - 6 } & & Young (Puppy) & 89 & 17 & 19.1 \\
\cline { 3 - 6 } & Cats- Adult & 96 & 18 & 18.75 \\
\cline { 3 - 6 } & & Young (Kitten) & 128 & 33 & 25.78 \\
\hline
\end{tabular}


Table 1. Epidemiological study of the prevalence of $M$. canis in dogs and cats, considering different variables (continued)

\begin{tabular}{|c|c|c|c|c|c|}
\hline Sl. $N^{o}$ & $\begin{array}{l}\text { Criteria/ } \\
\text { variables }\end{array}$ & Data & Total number & M. canis isolated & Prevalence (\%) \\
\hline \multirow{8}{*}{2.} & \multirow{8}{*}{ Sex } & Dogs- Adult male & 150 & 13 & 8.67 \\
\hline & & Adult female (Bitch) & 167 & 16 & 9.58 \\
\hline & & Dogs- Young male & 36 & 7 & 19.44 \\
\hline & & Young female & 53 & 10 & 18.87 \\
\hline & & Cats- Adult male (Tom) & 55 & 10 & 18.18 \\
\hline & & Adult female (Queen) & 41 & 8 & 19.51 \\
\hline & & Cats- Young male & 70 & 18 & 25.71 \\
\hline & & Young female & 58 & 15 & 25.86 \\
\hline \multirow{4}{*}{3.} & \multirow{4}{*}{$\begin{array}{l}\text { Place of } \\
\text { living }\end{array}$} & Dogs- Rural & 163 & 31 & 19.02 \\
\hline & & Urban & 243 & 15 & 6.17 \\
\hline & & Cats- Rural & 66 & 14 & 21.21 \\
\hline & & Urban & 158 & 37 & 23.42 \\
\hline \multirow{8}{*}{4.} & \multirow{8}{*}{ Season } & Dogs- Summer & 98 & 20 & 20.41 \\
\hline & & Autumn & 113 & 14 & 12.39 \\
\hline & & Monsoon/Rainy & 109 & 7 & 6.42 \\
\hline & & Winter & 86 & 5 & 5.81 \\
\hline & & Cats- Summer & 62 & 24 & 38.71 \\
\hline & & Autumn & 59 & 16 & 27.12 \\
\hline & & Monsoon/Rainy & 49 & 7 & 14.29 \\
\hline & & Winter & 54 & 4 & 7.41 \\
\hline
\end{tabular}

Table 2. In vitro antifungal susceptibility of $M$. canis isolates (97) from pet animals in West Bengal, India

\begin{tabular}{|l|l|c|c|c|}
\hline \multirow{2}{*}{ Sl. No. } & \multirow{2}{*}{ Antifungal drugs } & \multicolumn{2}{|c|}{ Minimum Inhibitory Concentration $(\mathrm{MIC})(\mu \mathrm{g} / \mathrm{mL})$} \\
\cline { 2 - 4 } & Range & MIC 50 & MIC 90 \\
\hline 1. & Fluconazole & $8-64$ & 16 & 32 \\
\hline 2. & Itraconazole & $0.03-1$ & 0.25 & 0.5 \\
\hline 3. & Ketoconazole & $0.03-1$ & 0.06 & 0.125 \\
\hline 4. & Griseofulvin & $0.06-2$ & 0.125 & 1 \\
\hline 5. & Miconazole & $0.03-0.5$ & 0.06 & 0.25 \\
\hline 6. & Amphotericin-B & $0.03-0.5$ & 0.06 & 0.125 \\
\hline
\end{tabular}




\section{Discussion}

With the changing scenario of demographic patterns throughout the globe, where the numbers of people undergoing chemotherapy, the immunocompromised, as well as organ transplant cases, are increasing day by day, the incidence of zoonotic fungal infections is also increasing (HAYETTE and SACHELI, 2015; VERMA and MADHU, 2017). The situation is further aggravated by the emergence of antifungal resistance (ALCAZAR-FUOLI and MELLADO, 2014; SINGH et al., 2018). Because the conventional procedures are time-consuming, require expertise, and are less sensitive and specific, molecular tools for the identification of dermatophytes are regarded as helpful.

The higher prevalence of $M$. canis reported in this study was also reported by other researchers (BINDU and. PAVITHRAN 2002; SINGH et al., 2018) and may be due to the climatic conditions of the study area, which is mostly hot and humid all year-round. Breed predisposition for $M$. canis is difficult and not well-reported in dogs as the treatment regimen is mostly based on dermatophytoses, and is not targeted towards the causative pathogen (MORIELLO et al., 2017). In our present case, the most commonly affected dogs were short breeds (Dachshund, Beagle, Pug) or had dense coats of hair (Labrador Retriever, Golden Retriever). A few similar studies have reported this prevalence in toy breeds and long-haired dogs (MANCIANTI et al., 2003; MORIELLO et al., 2017). The reason for this might be the ability of $M$. canis spores to become trapped in densely coated or long-haired animals, leading to carriage and sometimes persistent infections (CAFARCHIA et al., 2006). Persian cats were the most common breed to be infected with $M$. canis. This is because of their long hair and predisposition to this zoophilic dermatophyte (MANCIANTI et al., 2003; MORIELLO et al., 2017). In this present study, puppies and kittens showed a higher prevalence for M. canis. This susceptibility is perhaps because they are not completely immuno-competent. The findings of the present study are quite similar to the reports of researchers from different parts of the globe (GALUPPI et al., 2013; MORIELLO, 2019). There was no difference between the isolation of the dermatophyte between the sexes of the pet animals, which is supported by some previous studies (MANCIANTI et al., 2003; COPETTI et al., 2006). Dogs from rural holdings were more prone to $M$. canis infection, which was also probably due to differences in environmental hygiene, and easy mixing with other animals, as compared to animals living in urban areas which are usually kept in an enclosed space or household. The highest prevalence of cases during the summer season is probably due to the very hot and humid environmental conditions of the region, which is very much characteristic for tropical and sub-tropical climatic conditions.

In the present study, 10 isolates $(6.1 \%)$ resembled M. canis phenotypically, but the molecular diagnosis was unable to confirm the identity. Due to the pleomorphism of dermatophytes, many researchers have reported difficulty in confirmation based only on phenotypic characters (DENG et al., 2008; GNAT et al., 2019). Overlapping features and variability in dermatophytes are also not uncommon (DIONGUE et al., 2019). Thus, for accurate identification of dermatophytes, species-specific primers and/or sequencing of the internal transcribed spacer (ITS) gene of the ribosomal RNA is warranted.

The MIC 90 values reported from different parts of the world show Griseofulvin to be sensitive to dermatophytes (JESSUP et al., 2000; ARAUJO et al., 2009). In our study, the MIC 50 values for Ketoconazole, Miconazole, and Amphotericin-B were low, indicating the susceptibility of the isolates against these drugs, while MIC 50 and MIC 90 values for Fluconazole and Griseofulvin was on the higher side, indicating a tendency towards developing resistance of the isolates against these drugs.

\section{Conclusion}

M. canis has emerged as a global zoonotic pathogen which creates a potential hazard for human health, especially pet owners, because it is easily transmitted from both dogs and cats. The situation is aggravated further, particularly in the case of drug-resistant isolates as resistance to even one class of antifungals severely limits therapy and hampers patient management. Since antifungal drugs are limited, it is thus pertinent to identify the 
pathogen properly, and avoid the widespread use of antifungals, to stop and suppress the development of resistance.

\section{Conflict of interest}

The authors have no conflict of interest to declare.

\section{Acknowledgment}

The authors express their sincere gratitude to the Honorable Vice-Chancellor, West Bengal University of Animal and Fishery Sciences, Kolkata, India for providing the infrastructure, and the Indian Council of Agricultural Research (ICAR), New Delhi, India, for providing the necessary funds under the 'Outreach Programme on Zoonotic Diseases'.

\section{References}

ALCAZAR-FUOLI, L., E. MELLADO (2014): Current status of antifungal resistance and its impact on clinical practice. Br. J. Haematol. 166, 471-484.

DOI: 10.1111/BJH.12896

ARAÚJO, C. R., K. C. MIRANDA, O. D. FERNANDES, A. J. SOARES, M. D. SILVA (2009): In vitro susceptibility testing of dermatophytes isolated in Goiania, Brazil, against five antifungal agents by broth microdilution method. Rev. Inst. Med. Trop. $S p$. 51, 9-12.

DOI: $10.1590 /$ S0036-46652009000100002

BINDU, V., K. PAVITHRAN (2002): Clinico-mycological study of dermatophytosis in Calicut. Ind. J. Dermatol., Venereol. Leprol. 68, 259.

CAFARCHIA, C., D. ROMITO, G. CAPELLI, J. GUILLOT, D. OTRANTO (2006): Isolation of Microsporum canis from the hair coat of pet dogs and cats belonging to owners diagnosed with M. canis tinea corporis. Vet. Dermatol. 17, 327-331.

DOI: 10.1111/J.1365-3164.2006.00533.X

CANO, J., A. REZUSTA, M. SOLÉ, J. GIL, M. C. RUBIO, M. J. REVILLO, J. GUARRO (2005): Inter-single-sequencerepeat-PCR typing as a new tool for identification of Microsporum canis strains. J. Dermatol. Sci. 39, 17-21.

DOI: 10.1016/J.JDERMSCI.2005.01.016

COPETTI, M. V., J. M. SANTURIO, A. S. CAVALHEIRO, A. A. BOECK, J. S. ARGENTA, L. C. AGUiAR, S. H. ALVES (2006): Dermatophytes isolated from dogs and cats suspected of dermatophytosis in Southern Brazil. Acta. Sci. Vet. 34, 119-124.

DA-CUNHA, M. M., F. CAPOTE-BONATO, I. R. G. CAPOCI, D. V. BONATO, L. G. GHIZZI, P. PAIVALIMA, T. I. E. SVIDZINSKI (2019): Epidemiological investigation and molecular typing of dermatophytosis caused by Microsporum canis in dogs and cats. Prev. Vet. Med. 167, 39-45.

DOI: 10.1016/J.PREVETMED.2019.03.019
DENG, S., G. S. BULMER, R. SUMMERBELL, G. S. DEHOOG, Y. HUI, Y. GRASER (2008): Changes in frequency of agents of tinea capitis in school children from Western China suggest slow migration rates in dermatophytes. Sabouraudia. 46, 421-427.

DOI: $10.1080 / 13693780701883730$

DIONGUE, K., L. BRECHARD, M. C. SECK, M. NDIAYE, A. S. BADIANE, S. RANQUE, D. NDIAYE (2019): A comparative study on phenotypic versus ITS-Based molecular identification of dermatophytes isolated in Dakar, Senegal. Int. J. Microbiol. 1-6.

DOI: $10.1155 / 2019 / 6754058$

GALUPPI, R., J. F. C. LEVEQUE, V. BEGHELLI, C. BONOLI, M. MATTIOLI, F. OSTANELLO, P.A. ACCORSI (2013): Cortisol levels in cats' hair in presence or absence of Microsporum canis infection. Res. Vet. Sci. 95, 1076-1080. DOI: 10.1016/J.RVSC.2013.07.023

GARG, J., R. TILAK, A. GARG, P. PRAKASH, A. K. GULATI, G. NATH (2009): Rapid detection of dermatophytes from skin and hair. BMC Res. Notes. 2, 60.

DOI: 10.1186/1756-0500-2-60

GNAT, S., A. NOWAKIEWICZ, P. ZIEBA (2019): Taxonomy of dermatophytes-the classification systems may change but the identification problems remain the same. Adv Microbiol. 58, 49-58.

DOI: $10.21307 /$ PM-2019.58.1.049

HAYETTE, M. P., R. SACHELI (2015): Dermatophytosis, trends in epidemiology and diagnostic approach. Curr. Fungal. Infect. Rep. 9, 164-179.

DOI: $10.1007 / \mathrm{S} 12281-015-0231-4$

JESSUP, C. J, J. WARNER, N. ISHAM, I. HASAN, M. A. GHANNOUM (2000): Antifungal susceptibility testing of dermatophytes: establishing a medium for inducing conidial growth and evaluation of susceptibility of clinical isolates. J. Clin. Microbiol. 38,341-4.

DOI: 10.1128/JCM.38.1.341-344.2000

KONEMAN, E. W., G. D. ROBERTS (1985): Dermatophyte identification schema. Practical Laboratory Mycology. $3^{\text {rd }}$ ed. Williams \& Wilkins, Baltimore.

LIU, D., L. PEARCE, G. LILLEY, S. COLOE, R. BAIRD (2001): A specific PCR assay for the dermatophyte fungus Microsporum canis. Med. Mycol. 39, 215-219.

DOI: $10.1080 / 714031019$

MANCIANTI, F., S. NARDONI, S. CECCHI, M. CORAZZA, F. TACCINI (2003): Dermatophytes isolated from symptomatic dogs and cats in Tuscany, Italy during a 15-year-period. Mycopathol. 156, 13-18.

DOI: 10.1023/A:1021361001794

MARAKI, S., E. NIOTI, E. MANTADAKIS, Y. TSELENTIS (2007): A 7-year survey of dermatophytoses in Crete, Greece. Mycoses. 50, 481-484.

DOI: 10.1111/J.1439-0507.2007.01403.X 
MIGNON, B. R., B. J. LOSSON (1997): Prevalence and characterization of Microsporum canis carriage in cats. J. Med. Vet. Mycol. 35, 249-256.

DOI: $10.1080 / 02681219780001231$

MITCHELL, T. G., R. L. SANDIN, B. H. BOWMAN, W. MEYER, W. G. MERZ (1994): Molecular mycology: DNA probes and applications of PCR technology. J. Med. Vet. Mycol. 32, 351-366.

DOI: $10.1080 / 02681219480000961$

MORIELLO, K. A., K. COYNER, S. PATERSON, B. MIGNON (2017): Diagnosis and treatment of dermatophytosis in dogs and cats. Clinical Consensus Guidelines of the World Association for Veterinary Dermatology. Vet. Dermatol. 28, 266-268.

DOI: $10.1111 / \mathrm{VDE} .12440$

MORIELLO, K (2019): Dermatophytosis in cats and dogs: a practical guide to diagnosis and treatment. In. Pract. 41, 138-147.

DOI: 10.1136/INP.L1539

NCCLS - National Committee For Clinical Laboratory Standards (2002): Reference method for broth dilution antifungal susceptibility testing of filamentous fungi. Approved standard M38-A. National Committee for Clinical Laboratory Standards, Wayne, Pa.

PANASITI,V.,R.G.BORRONI,V.DEVIRGILIIS,M.ROSSI,L. FABBRIZIO, R. MASCIANGELO, S. CALVIERI (2006):
Comparison of diagnostic methods in the diagnosis of dermatomycoses and onychomycoses. Mycoses. 49, 26-29.

DOI: 10.1111/J.1439-0507.2005.01185.X

RAJAGOPALAN, M., A. INAMADAR, A. MITTAL, A. K. MISKEEN, C. R. SRINIVAS, K. SARDANA, S. DOGRA (2018): Expert consensus on the management of dermatophytosis in India. BMC. Dermatol. 18, 6.

DOI: $10.1186 / \mathrm{S} 12895-018-0073-1$

RENGASAMY, M., J. CHELLAM, S. GANAPATI (2017): Systemic therapy of dermatophytosis: Practical and systematic approach. Clin. Dermatol. Rev. 1, 19.

DOI: 10.4103/CDR.CDR_36_17

ROBERT, R., M. PIHET (2008): Conventional methods for the diagnosis of dermatophytosis. Mycopathologia. 166, 295306.

DOI: $10.1007 /$ S11046-008-9106-3

SINGH, A., C. DEBNATH, A. BANERJEE, K. BATABYAL, B. ROY, I. SAMANTA (2018): Effects of propylene glycol and magnesium chloride against dermatophytes isolated from companion animals. Ind. J. Ani. Health. 57, 213-218. DOI: 10.36062/IJAH.57.2.2018.213-218

VERMA, S., R. MADHU (2017): The great Indian epidemic of superficial dermatophytosis: an appraisal. Ind. J. Dermatol. $62,227$.

\section{SINGH, A. D., C. DEBNATH, A. BANERJEE: Epidemiološko istraživanje, karakterizacija i protugljivična osjetljivost gljivice Microsporum canis izolirane iz kućnih ljubimaca. Vet. arhiv 91, 339-347, 2021. \\ SAŽETAK}

Dermatofitoze su su dugo poznate bolesti u ljudi i životinja kod kojih sve više zabrinjava razvoj protugljivične otpornosti. Među brojnim etiologijama ključnu ulogu ima Microsporum canis. U ovom je radu istražena epidemiologija, provedena karakterizacija i istražena protugljivična osjetljivost gljivice M. canis izolirane iz kućnih ljubimaca. Metodom PCR-a kao vrsta $M$. canis identificirano je ukupno 97 izolata $(59,15 \%), 46$ kod pasa i 51 kod mačaka. Uvažavajući dob, prevalencija gljivice $M$. canis bila je najveća u štenadi $(19,1 \%)$ i mačića $(25,78 \%)$. U ovom istraživanju nije potvrđena spolna predispozicija bolesti. Sezonska raspodjela najveća je bila ljeti, a najmanja zimi. U nekoliko je izolata promatrana rezistencija na Flukonazol i Grizeofulvin. Rezultati upućuju na to da treba točno identificirati patogen i biti oprezan u izboru lijeka kako bi se spriječio daljnji razvoj dermatofita.

Ključne riječi: dermatofit; psi; mačke; PCR; rezistencija na lijek 
